\title{
MODEL PENGELOLAAN BADAN USAHA MILIK DESA (BUMDES) DALAM MEMBANGUN PEREKONOMIAN DESA (Studi Kasus Desa Masalima)
}

\author{
Ryan Marala, Hendro Wibowo dan \\ Rachmat Rizky Kurniawan 1,6
}

\footnotetext{
${ }^{1,6}$ Afiliasi: Sekolah Tinggi Ekonomi Islam SEBI. Email: ryanmaralaalfarizy@gmail.com, hendro.wibowo83@gmail.com,Rah.rizqy@gmail.com
}

\begin{abstract}
ABSTRAK. Penulis melakukan penelitian Model Pengelolaan Badan Usaha Milik Desa (BUMDes) dalam Membangun Perekonomian Desa. Tujuannya adalah untuk Mengetahui dan mengenal daya tarik dan potensi Desa masalima untuk bisa dioptimalkan dan mengetahui cara mendirikan Badan Usaha Milik Desa (BUMDes) serta mengetahui Model Pengelolaan Badan Usaha Milik Desa (BUMDes) dalam meningkatkan perekonomian masyarakat Desa Masalima. Metode penelitian yang digunakan adalah jenis penelitian kualitatif dengan penjabaran deskriptif yaitu suatu penelitian yang bertujuan untuk memperoleh gambaran untuk memahami dan menjelaskan model pengelolaan Badan Usaha Milik Desa (BUMDes) dalam Membangun Perekonomian Desa. Dalam penelitian ini penulis menganalisis apa saja potensi yang bisa di kembangkan di Desa Masalima sehingga bisa di kembangkan dan diolah melalui Badan Usaha Milik Desa (BUMDes).
\end{abstract}

Kata Kunci : Pengelolaan, BUMDes, Desa Masalima

\begin{abstract}
The author conducts research Model Management of Village Owned Enterprises (BUMDes) in Building Village Economy. The goal is to know and recognize the attraction and potential of Masalima Village to be optimized and know how to set up Village Owned Enterprises (BUMDes) as well as to know the Model Management of BUMDes in improving the economy of Masalima Village community. The research method used is the type of qualitative research with descriptive description is a study that aims to obtain a picture to understand and explain the model management of Village Owned Enterprises (BUMDes) in Developing the Village Economy. In this study the authors analyze what potentials can be developed in Masalima Village so that it can be developed and processed through the Village Owned Enterprises (BUMDes).
\end{abstract}

Keywords: Management, BUMDes, Masalima Village

\section{PENDAHULUAN}


Indonesia adalah salah satu negara maritim yang mempunyai potensi laut yang sangat besar, karena terdapat berbagai macam biota laut yang berbeda-beda sehingga dapat menciptakan dan meningkatkan pendapatan negara. Potensi laut yang ada di idonesia tidak dapat di biarkan begitu saja. Kekayaan laut indonesia dapat menjadi sumber pendapatan yang besar dan memiliki prospek yang sangat cerah dikemudian hari bagi sebuah pembangunan nasional.

Dengan meningkatnya gaya hidup manusia baik di seluruh dunia maupun di indonesia khususnya, dimana lebih menyukai sesuatu yang instan dan cepat saji. Hal ini merupakan gejala yang mendasar bagi manusia yang mendorong sifat selektif terhadap gaya hidupnya. Kebutuhan yang instan dan cepat saji tersebut, tidak terkecuali pada kebutuhan konsumsi masyarakat indonesia yang menginginkan makanan sehat dan cepat saji diantaranya makanan khas laut yang saat ini banyak diminati oleh masyarakat indonesia.

Disinilah peran ekonomi kreatif harus dioptimalkan. peran pemerintah sangatlah penting, untuk menunjang keberhasilan dan pengembangan pengelolaan hasil laut. Denga adanya pengelolaan yang baik dari pemerintah diharapkan meningkatkan pendapatan untuk menunjang perekonomian nasional maupun daerah. Hal tersebut akan memberikan dampak dan pengaruh yang sangat positif yang ungkin timbul dari pengembangan ini adalah perluasan kesempatan kerja.

Desa Masalima yang terletak di Kecamatan Masalembu, Kabupaten Sumenep, Provinsi Jawa Timur, merupakan salah satu desa yang mempunyai kekayaan laut yang besar. Secara ekologis-geografis, desa Masalima di Kepulaun Masalembu terletak pada posisi lintang : $5^{\circ} 31^{\prime}$ sampai dengan $5^{\circ}$ 35' LS. Dengan posisi ini, kedudukan Desa Masalima di Kepulaun Masalembu mendekati posisi ekuatorial (garis khatulistiwa) dengan ciri-ciri lingkungan yang spesifik, yaitu mempunyai daya tampung yang sangat tinggi terhadap struktur biodiversitas habitat, seperti terumbu karang, bakau, telu, pesisir litoral, rumput laut (algae), dan daerah umbalan (upwelling area) yang menjadi penopang sumber daya ikan dan non-ikan dengan nilai ekonomis yang tinggi. Kondisi ini menyebabkan Desa Masalima di Kepulaun Masalembu langsung berbatasan dengan perairan bebas (laut lepas).

Potensi utama Desa Masalima adalah potensi laut. dengan potensi laut yang sangat besar, harusnya ada suatu lembaga desa setempat yang bisa mengolah hasil laut tersebut sehingga bisa menghasilkan pendapatan murni dari desa tersebut yang signifikan setiap tahun. Akan tetapi, fenomena yang terjadi pada desa Masalima saat ini adalah dengan mayoritas penduduknya adalah nelayan, kemudian hasil tangkap ikan dijual langsung ke tengkulak ikan walaupun terkadang harga yang ditawarkan tidak sesuai dengan harga normalnya sehingga pendapatan nelayan tidak maksimal. Kemudian musim melaut pada Desa Masalima kurang lebih hanya tujuh bulan, selepas itu masyarakat Masalima hanya ada dua pilihan yang dilakukan apabila musim ikan berakhir yaitu menentap di Desa Masalima dengan menggunakan tabungan atau bekerja sampingan untuk bertahan hidup sampai musim melaut 
Jurnal Ekonomi dan Perbankan Syariah

Vol. 6. No.1, April 2018: 107-134, ISSN (cet): 2355-1755 | ISSN (online): 2579-

6437

\section{3}

datang lagi, atau keluar dari Desa Masalima pergi ke kota-kota besar untuk mencari pekerjaan lain sampai musim melaut datang lagi.

Oleh karena itu, sesuai dengan amanat UU No. 6 / 2014 maka desa mendapat peluang besar untuk meningkatkan perannya dalam pengembangan ekonomi masyarakat perdesaan. Dalam meningkatkan ekonomi masyarakat pedesaan, membentuk suatu Badan Usaha Milik Desa (BUMDesa) adalah salah satu langkah yang tepat. BUMDes pun dapat menjadi instrumen dan mengoptimalkan perannya sebagai lembaga ekonomi lokal yang legal ditingkat desa untuk meningkatkan kesejahteraan masyarakat dan pendapatan desa (Purnamasari, 2014).

Untuk mewujudkan adanya BUMDesa yang memanfaatkan potensi laut desa Masalima, tentunya perangkat desa bisa memanfaatkan dana desa yang terus mengalami peningkatan setiap tahunnya. Adapun rincian dana desa 2015 telah ditetapkan dalam Peraturan Presiden Republik Indonesia no. 36 tahun 2015 tentang rincian Anggaran Pendapatan dan Belanja Negara (APBN) tahun anggaran 2015, rincian dana desa menurut Kabupaten/ Kota menyebutkan total nasional dana desa sebesar 20,77 T. dan Dana desa terus mengalami peningkatan di tahun 2016, Peraturan Presiden Republik Indonesia no. 137 tahun 2015 tentang rincian Anggaran Pendapatan dan Belanja Negara (APBN) tahun anggaran 2016, rincian dana desa menurut Kabupaten/ Kota menyebutkan total nasional dana desa sebesar 46,98 T. Hal ini meningkat menjadi $26,21 \mathrm{~T}$ dari tahun sebelumnya atau meningkat sebesar $127 \%$ dari tahun 2015, kemudian dalam Peraturan Presiden Republik Indonesia no. 97 tahun 2016 tentang rincian Anggaran Pendapatan dan Belanja Negara (APBN) tahun anggaran 2017, rincian dana desa menurut Kabupaten/ Kota menyebutkan total nasional dana desa sebesar 60,00 $\mathrm{T}$ atau meningkat sebesar 27\% dari tahun sebelumnya. Kemudian untuk tahun 2018 sesuai dengan rincian alokasi transfer ke Daerah dan Dana Desa Provinsi/Kabupaten dalam APBN tahun anggaran 2018, menyebutkan total nasional dana desa sebesar $60,00 \mathrm{~T}$.

Tabel 1.1 Alokasi Dana Desa Nasional

\begin{tabular}{|l|l|c|}
\hline \multicolumn{1}{|c|}{ Tahun } & \multicolumn{1}{|c|}{ Jumlah Dana (Rp) } & Trend \\
\hline 2015 & $20.770 .000 .000 .000,-$ & \\
\hline 2016 & $46.982 .080 .000 .000,-$ & $127 \%$ \\
\hline 2017 & $60.000 .000 .000 .000,-$ & $27 \%$ \\
\hline 2018 & $60.000 .000 .000 .000,-$ & \\
\hline
\end{tabular}

Sumber : Direktorat Jendral Anggaran Kementerian Keuangan Republik Indonesia, diolah 
Untuk Bumdes di Indonesia sendiri atau secara nasional bergerak di beberapa bidang atau unit, antara lain unit pasar Desa, unit perdagangan, unit simpan pinjam, unit pengairan, unit pariwisata, unit persewaan aset Desa, unit pertanian, unit peternakan, unit jasa pelayanan.

Untuk mengetahui jenis usaha apa yang akan dikelola pada BUMDes di suatu Daerah, maka harus mengetahui terlebih dahulu potensi yang ada di Daerah tersebut. Oleh karena itu, harus mengetahui terlabih dahulu alokasi dana desa yang ada pada tiap-tiap daerah.

Untuk alokasi masing-masing wilayah khususnya kabupaten sumenep pada tahun 2015 jika dibandingkan dari dana secara nasional, kabupaten sumenep mendapatka bagian sekitar $1 \%$ atau lebih tepatnya $0,46 \%$, namun tahun 2016 secara Nasional bagian Kabupaten Sumenep sebesar 0,47\% meningkat dari tahun sebelumnya hingga tahun 2017 0,45\% serta 2018 meningkat sebesar $0,46 \%$ dari tahun sebelumnya.

Tabel 1.2 Alokasi Dana Desa Kabupaten Sumenep

\begin{tabular}{|l|l|l|}
\hline \multicolumn{1}{|c|}{ Tahun } & \multicolumn{1}{|c|}{ Jumlah } & \multicolumn{1}{c|}{ Trend } \\
\hline 2015 & 94.880 .517 & \\
\hline 2016 & 221.984 .150 & $133 \%$ \\
\hline 2017 & 271.773 .005 & $23 \%$ \\
\hline 2018 & 276.309 .656 & $1,7 \%$ \\
\hline
\end{tabular}

Sumber : Direktorat Jendral Anggaran Kementerian Keuangan Republik Indonesia, diolah

Dengan peningkatan dana desa tiap tahunnya khususnya Kabupaten Sumenep, dapat dioptimalkan dengan mengelola sumber daya laut yang ada di Desa Masalima sehingga dapat menanggulangi permasalahan yang ada, dengan meningkatkan potensi ekonomi dan sumber daya desa yang ada.

Untuk desa Masalima, dari tahun 2014 sampai 2016 hanya ada 1 pasar umum yang aktif dan belum ada pasar hewan dan pasar ikan, dan ada 39 Toko hingga saat ini meningkat menjadi 48 Toko. Hal ini memicu untuk menciptakan pasar, dalam hal ini khususnya pasar ikan.

Tabel 1.3 Jumlah Sarana Perekonomian Desa Masalima

\begin{tabular}{|l|l|l|l|l|l|}
\hline \multicolumn{1}{|c|}{ Tahun } & $\begin{array}{c}\text { Pasar } \\
\text { Umum }\end{array}$ & $\begin{array}{c}\text { Pasar } \\
\text { Hewan }\end{array}$ & $\begin{array}{c}\text { Pasar } \\
\text { Ikan }\end{array}$ & Toko \\
\hline 2014 & 1 & - & - & 39 \\
\hline 2015 & 1 & - & - & 48 \\
\hline 2016 & 1 & - & - & 48 \\
\hline
\end{tabular}

Sumber : Kecamatan Masalembu dalam Angka, diolah 
Jurnal Ekonomi dan Perbankan Syariah

Vol. 6. No.1, April 2018: 107-134, ISSN (cet): 2355-1755 | ISSN (online): 2579-

6437

| 105 
106 | Ryan Marala: Model Pengelolaan Badan Usaha Milik Desa (BUMDes) Dalam Membangun Perekonomian Desa (Studi Kasus Desa Masalima)

Tabel 1.4 Jumlah Rumah Tangga Sektor Pertanian Menurut Desa dan Lapangan Pekerjaan

\begin{tabular}{|l|l|}
\hline \multicolumn{1}{|c|}{ Tahun } & \multicolumn{1}{c|}{ Perikanan } \\
\hline 2014 & 1.265 \\
\hline 2015 & 1.260 \\
\hline 2016 & 1.760 \\
\hline
\end{tabular}

Sumber : Kecamatan Masalembu dalam Angka, diolah

Berdasarkan data diatas terlihat bahwa permasalahan utama dan menjadi salah satu alasan mengapa harus ada Badan Usaha Milik Desa (BUMDes) yaitu belum optimalnya pengelolaan sumber daya dan potensi yang ada di Desa Masalima. Berdasarkan jumlah Rumah Tangga yang bergerak dalam lapangan pekerjaan Perikanan, sehingga hasil dari perikanan harus dioptimalkan dengan diakomodir oleh Badan Usaha Milik Desa (BUMDes).

Mengingat pentingnya mengoptimalkan potensi yang ada di desa dengan pengelolaan berbasis BUMDes, maka menarik untuk diteliti bagaimana model pengelolaan BUMDes dalam meningkatkan perekonomian Desa Masalima.

\section{LANDASAN TEORI}

\subsection{MODEL PENGELOLAAN}

\section{a. Pendekatan State-Based dan Community-Based}

\section{1) Pendekatan State-Based}

Sebagaimana kebijakan pengelolaan lingkungan di Indonesia bahwa pengelolaan lingkungan dengan pendekatan state-based di dasarkan pada pendekatan "top down", dimana dilaksanakan karena ada anggapan bahwa penduduk yang berpenghasilan rendah tidak memiliki pengetahuan teknis yang dibutuhkan untuk memberikan kontribusi efektif dalam proses perencanaan (Wijanarko, 2006).

Pendekatan state-based mengandung arti bahwa komitmen pemerintah terhadap partisipasi masyarakat terbatas. Hal ini menandakan bahwa apabila mendirikan suatu lembaga pemberdayaan masyarakat, tidak akan berjalan seimbang untuk kedepannya. Seimbang dalam arti kalaborasi antara pemerintah dan masyarakat tidak sama rata.

\section{2) Pendekatan Community-Based}

Pengalaman dengan banyak hal di Indonesia bahwa pendekatan community-based menunjukkan bahwa pendekatan ini tidak selalu dapat mengembangkan pengelolaan lingkungan dalam jangka panjang dan berskala luas (Wijanarko,2006). Pada pendekatan Community-Based cendrung mengesampingkan peran pemerintah. Dalam artian pemerintah berjalan sendiri begitu juga masyarakatnya menggunakan cara sendiri tanpa ada koordinasi konkrit dengan pemerintah. 
Jurnal Ekonomi dan Perbankan Syariah

Vol. 6. No.1, April 2018: 107-134, ISSN (cet): 2355-1755 | ISSN (online): 2579-

6437

\section{7}

\section{b. Pendekatan Co-Management}

Co-management juga dinamakan pengelolaan kolaboratif, pengelolaan partisipatif atau pengelolaan berbasis masyarakat (Wijanarko, 2006). Pendekatan Co-Management adalah alternatif potensial untuk mengisi kelemahan dari pendekatan State-based dan Community-based.

Dalam Co-Management bentuk pengelolaan sumberdaya alam berupa gabungan dari dua pendekatan utama yaitu pengelolaan yang dilakukan oleh pemerintah (Goverment Centralized Management) dan pengelolaan yang dilakukan oleh masyarakat (Community Based Management). Pada Goverment Centralized Management, hirarki yang tertinggi hanya memberikan informasi kepada masyarakat, dan selanjutnya dilakukan oleh pemerintah. Sedangkan pada Community Based Management, hirarki yang tertinggi adalah control yang ketat dari masyarakat dan koordinasi antar area yang dilakukan oleh masyarakat itu sendiri (Susilowati, 2012).

\subsection{PENGELOLAAN}

\section{Pengertian Pengelolaan}

Pengelolaan diartikan sebagai suatu rangkaian pekerjaan atau usaha yang dilakukan oleh sekelompok orang untuk melakukan serangkaian kerja dalam mencapai tujuan tertentu. Dikatakan manajemen adalah suatu proses perencanaan dan pengambilan keputusan, pengorganisasian, memimpin dan pengendalian organisasi manusia, keuangan, fisik dan informasi sumber daya untuk mencapai tujuan organisasi secara efisiensi dan efektif.

Menurut Balderton, pengelolaan yaitu menggerakan, mengorganisasikan dan mengarahkan usaha manusia untuk memanfaatkan secara efektif material dan fasilitas untuk mencapai suatu tujuan (dalam Adisasmita, 2011). Pengelolaan bukan hanya melaksanakan suatu kegiatan, akan tetapi merupakan rangkaian kegiatan yang meliputi fungsi-fungsi manajemen, seperti perencanaan, pelaksanaan dan pengawasan untuk mencapai tujuan secara efektif dan efisien (Adisasmita, 2011).

\section{Badan Usaha Milik Desa}

\section{a. Pengertian Badan Usaha Milik Desa (BUMDes)}

Menurut Undang-undang No. 06 Tahun 2014 tentang desa, yang dimaksud dengan badan usaha milik desa (BUMDes) adalah badan usaha yang seluruh atau sebagian besar modalnya dimiliki oleh desa melalui penyertaan secara langsung yang berasal dari kekayaan desa yang dipisahkan guna mengelola aset, jasa pelayanan dan usaha lainnya untuk sebesar-besarnya kesejahteraan masyarakat desa.

Badan Usaha Milik Desa, selanjutnya disebut BUM Desa, adalah badan usaha yang seluruh atau sebagian besar modalnya dimiliki oleh Desa melalui penyertaan secara langsung yang berasal dari kekayaan Desa yang dipisahkan guna mengelola aset, jasa pelayanan, dan usaha lainnya untuk sebesarbesarnya kesejahteraan masyarakat Desa (Permendes, 2015). 


\subsection{PENGERTIAN PEREKONOMIAN DESA}

Ekonomi artinya aturan rumah tangga atau manajemen rumah tangga. Ekonomi juga dikatakan sebagai ilmu yang menghasilkan, mengedarkan, membagi serta memakai barang dan jasa dalam masyarakat sehingga kebutuhan materi masyarakat dapat terpenuhi. Kegiatan ekonomi dalam masyarakat adalah mengatur urusan kekayaan baik yang menyangkut kepemilikan, pengembangan maupun distribusi (Sholahuddin, 2007) Manusia hidup dalam suatu kelompok yang membentuk suatu sistem. Sistem secara sederhana dapat diartikan sebagai interaksi, kaitan, atau hubungan dari unsurunsur yang lebih kecil membentuk satuan yang lebih besar dan komplek sifatnya. Dengan demikian sistem ekonomi adalah interaksi dari unit-unit yang kecil (para konsumen dan produsen) ke dalam unit ekonomi yang lebih besar disuatu wilayah tertentu (Deliarnov, 2009).

\section{METODOLOGI PENELITIAN \\ 3.1 JENIS PENELITIAN}

Jenis penelitian ini merupakan penelitian kualitatif dengan penjabaran deskriptif yaitu suatu penelitian yang bertujuan untuk memperoleh gambaran untuk memahami dan menjelaskan model pengelolaan Badan Usaha Milik Desa (BUMDes) dalam Membangun Perekonomian Desa. Metode penelitian kualitatif adalah metode penelitian yang berlandaskan pada filsafat postpositivisme, digunakan untuk meneliti pada kondisi obyek yang alamiah, (sebagai lawannya adalah eksperimen) dimana peneliti adalah sebagai instrumen kunci, teknik pengumpulan data dilakukan secara triangulasi (gabungan), analisis data bersifat induktif/kualitatif, dan hasil penelitian kualitatif lebih menekankan makna dari pada generalisasi (Sugiyono, 2017).

\subsection{TEKNIK PENGUMPULAN DATA}

Teknik pengumpulan data merupakan langkah yang paling strategis dalam penelitian, karena tujuan utama dari penelitian adalah mendapatkan data. Tanpa mengetahui teknik pengumpulan data, maka peneliti tidak akan mendapatkan data yang memenuhi standar data yang di tetapkan. Pengumpulan data dapat dilakukan dalam berbagai setting, berbagai sumber, dan berbagai cara. bila dilihat dari settingnya, data dapat dikumpulkan pada setting alamiah (natural setting), pada laboratorium dengan metode eksperimen, di rumah dengan berbagai responden, pada suatu seminar, diskusi, di jalan dan lain-lain. Bila dilihat dari sumber datanya, maka pengumpulan data dapat menggunakan sumber primer, dan sumber sekunder. Sumber primer adalah sumber data yang langsung memberikan data kepada pengumpul data, dan sumber sekunder merupakan sumber yang tidak langsung memberikan data kepada pengumpul data, misalnya lewat orang lain atau lewat dokumen. Adapun macam-macam teknik pengumpulan data antara lain observasi, wawancara, Dokumentasi, dan triangulasi/gabungan (Sugiyono, 2017). Macam-macam teknik pengumpulan data :

a. Observasi

Observasi adalah bagian dalam pengumpulan data. Observasi berarti mengumpulkan data langsung dari lapangan. Dengan observasi si peneliti akan 
Jurnal Ekonomi dan Perbankan Syariah

Vol. 6. No.1, April 2018: 107-134, ISSN (cet): 2355-1755 | ISSN (online): 2579 6437

\section{9}

mendapatkan pengalaman dan pengetahuan yang sangat personal yang terkadang sulit diungkapkan dengan kata-kata. Pengetahuan itu menjadi dasar untuk refleksi dan introspeksi. Pengetahuan ini lebih dari data yang tertulis, karena dialami langsung. Maksud utama observasi adalah menggambarkan keadaan yang diobservasi. Kualitas penelitian ditentukan oleh seberapa jauh dan mendalam peneliti mengerti tentang situasi dan konteks dan menggambarkannya sealamiah mungkin (Dr. J.R. Raco, M.E., 2010).

\section{b. Wawancara}

Wawancara (interview) dilakukan untuk mendapatkan informasi, yang tidak dapat diperoleh melalui observasi atau kuesioner. Ini disebabkan oleh karena peneliti tidak dapat mengobservasi seluruhnya. Tidak semua data dapat diperoleh dengan observasi. Oleh karena itu peneliti harus mengajukan pertanyaan kepada partisipan. Pertanyaan sangat penting untuk menangkap persepsi, pikiran, pendapat, perasaan orang tentang suatu gejala, peristiwa, fakta atau realita. Dengan mengajukan pertanyaan peneliti masuk dalam alam berpikir orang lain, mendapatkan apa yang ada dalam pikiran mereka dan mengerti apa yang mereka pikirkan. Karena persepsi, perasaan, pikiran orang sangat berarti, dapat dipahami dan dapat dieksplisitkan dan dianalisis secara ilmiah (Raco , 2010).

\section{c. Dokumentasi}

Data penelitian kualitatif biasanya berbentuk teks, foto, cerita, gambar, artifacts dan bukan berupa angka hitung-hitungan. Data dikumpulkan bilamana arah dan tujuan penelitian sudah jelas dan juga bila sumber data yaitu informan atau partisipan sudah diintifikasi, dihubungi serta sudah mendapatkan persetujuan atas keinginan rnereka untuk mernberikan informasi yang dibutuhkan (Raco, 2010).

Dokumentasi merupakan catatan peristiwa yang sudah berlalu. Dokumentasi bisa berbentuk tulisan, gambar, atau karya-karya monumental dari seseorang. Dokumentasi yang berbentuk tulisan misalnya catatan harian, sejarah kehidupan (life histories), cerita, biografi, peraturan, kebijakan. Dokumentasi yang berbentuk gambar, misalnya foto, gambar hidup, sketsa dan lain-lain. Dokumentasi yang berbentuk karya misalnya karya seni, yang dapat berupa gambar, patung, film, dan lain-lain. Studi dokumentasi merupakan pelengkap dari penggunaan metode observasi dan wawancara dalam penelitian kualitatif ( Sugiyono, 2017).

Dalam penelitian ini, dalam pengumpulan data peneliti menggunakan purposive sampling. Dimana purposive sampling adalah teknik pengambilan sampel sumber data dengan pertimbangan tertentu.pertimbangan tertentu ini, misalnya orang tersebut yang dianggap paling tahu tentang apa yang kita harapkan, atau mungkin dia sebagai penguasa sehingga akan memudahkan peneliti menjelajahi obyek/situasi sosial yang diteliti (Sugiyono, 2017). Dalam penelitian ini, peneliti hanya melakukan wawancara pada anggota organisasi nelayan dan kepala Desa Masalima. 


\section{JENIS DATA}

Jenis data yang digunakan dalam penelitian ini meliputi data primer dan data sekunder:

a. Data Primer yaitu data yang diperoleh secara langsung dari sumber asalnya atau diperoleh dari lapangan yang merupakan data empirik. data empirik yang dimaksud adalah hasil wawancara dengan beberapa pihak atau informan yang benar-benar berkompeten dan bersedia memberikan data dan informasi yang dibutuhkan dan relevan dengan kebutuhan penelitian. Salah satunya kepala bagian atau instansi yang terkait dalam penelitian (Hutami, 2017). Dalam penelitian ini teknik pengambilan data primer melalui wawancara secara langsung terkait potensi desa. Sumber data yang didapat dari hasil wawancara dengan aparatur desa, serta masyarakat desa terkait.

b. Data sekunder merupakan data yang diperoleh secara tidak langsung dari objek yang diteliti yang antara lain dilakukan melalui studi literatur, kepustakaan dan arsip/laporan (Sulastri, 2016). Dalam penelitian ini dengan mempelajari berbagai literatur-literatur terkait yang mendukung data penelitian seperti peraturan, buku, jurnal maupun artikel-artikel ilmiah yang terkait dengan pengelolaan BUMDes dalam penelitian ini.

\section{OBJEK PENELITIAN}

Dalam penelitian ini, agar penelitian tetap terfokus pada satu masalah maka membutuhkan suatu objek penelitian yang sesuai dengan pembahasan. Objek dari penelitian ini adalah salah satu Desa yang berada di Jawa Timur yaitu Desa Masalima Kabupaten Sumenep. Dan dalam pembahasan ini terfokus pada pengelolaan Badan Usaha Milik Desa (BUMDes) di Desa Masalima. 
Jurnal Ekonomi dan Perbankan Syariah

Vol. 6. No.1, April 2018: 107-134, ISSN (cet): 2355-1755 | ISSN (online): 2579-

6437

\section{| 111}

\section{INSTRUMEN PENELITIAN}

Dalam penelitian Model Pengelolaan Badan Usaha Milik Desa ( BUMDes) dalam Membangun Perekonomian Desa studi kasus Desa Masalima, yang menjadi instrumen utama penelitian adalah peneliti sendiri. Peneliti kualitatif sebagai human instrument, berfungsi sebagai sumber data, melakukan pengumpulan data, menilai kualitas data, menafsirkan data dan membuat kesimpulan atas temuannya.

Dalam hal instrumen kualitatif, menurut Nasution menyatakan Dalam penelitian kualitatif, tidak ada pilihan lain daripada menjadikan manusia sebagai instrumen penelitian utama. Alasannya ialah bahwa, segala sesuatunya belum mempunyai bentuk yang pasti. Masalah, fokus penelitian, prosedur penelitian, hipotesis yang digunakan, bahkan hasil yang diharapkan itu semuanya tidak dapat ditentukan secara pasti dan jelas sebelumnya. Segala sesuatu masih perlu dikembangkan sepanjang penelitian itu. Dalam keadaan yang tidak pasti dan tidak jelas itu, tidak ada pilihan lain dan hanya peneliti itu sendiri sebagai alat satu-satunya yang dapat mencapainya (Sugiyono, 2017).

Berdasarkan pernyataan diatas dapat dilihat bahwa, dalam penelitian kualitatif permasalahan yang ada dilapangan awalnya belum jelas dan pasti, maka yang menjadi instrumen adalah peneliti itu sendiri.

\section{TEKNIK ANALISIS DATA}

Metode kualitatif merubah data menjadi temuan (findings). Memang tidak ada formula untuk itu Tidak ada alat ukur untuk mengetahui validitas dan realibilitas, Tidak ada aturan yang absolute. Metode kualitatif bersifat induktif yaitu mulai dari fakta, realita, gejala, masalah yang diperoleh melalui suatu observasi khusus. Dari realita dan fakta yang khusus ini kemudian peneliti membangun pola-pola umum. Induktif berarti bertitik tolak dari yang khusus ke umum. Sifat lain dari metode ini adalah holistik. Peneliti yang menggunakan metode ini berkeinginan untuk memahamai suatu gejala secara menyeluruh, termasuk mendeskripsikan dan menginterpretasikan lingkungan sosial manusia atau organisasi eksternal yang mempengaruhinya (Raco, 2010).

Analisis data kualitatif adalah bersifat induktif, yaitu suatu fakta berdasarkan data yang diperoleh, selanjutnya dikembangkan menjadi hipotesis yang dirumuskan berdasarkan data tersebut. Selanjutnya dicarikan data lagi secara berulang-ulang sehingga selanjutnya dapat disimpulkan apakah hipotesis tersebut diterima atau ditolak berdasarkan data yang terkumpul (Sugiyono, 2017).

Untuk proses analisis data pada penelitian kualitatif, ada beberapa tahap dan proses yaitu :

a. Analisis sebelum di lapangan

Penelitian kualitatif telah melakukan analisis data sebelum peneliti memasuki lapangan. Analisis dilakukan terhadap data hasil studi pendahuluan, atau data sekunder, yang akan digunakan untuk menentukan fokus penelitian. 
b. Analisis data di lapangan

Dilakukan pada saat pengumpulan data berlangsung, dan setelah selesai pengumpulan data dalam periode tertentu. Pada saat wawancara, peneliti sudah melakukan analisis terhadap jawaban yang diwawancarai.

\section{PEMBAHASAN}

\subsection{DESKRIPSI OBJEK PENELITIAN}

Deskripsi objek penelitian ini akan menjelaskan tentang objek penelitian yang meliputi lokasi penelitian secara jelas dari objek yang diteliti dan memberikan gambaran umum model pengelolaan Badan Usaha Milik Desa dalam Membangun Perekonomia Desa Masalima Kecamatan Masalembu kabupaten sumenep, Jawa Timur. Hal tersebut akan dipaparkan sebagai berikut.

\subsubsection{Gambaran Umum Desa Masalima}

Desa Masalima merupakan salah satu desa di Pulau Masalembu yang memiliki jarak tempuh selama 18 jam ke kabupaten Sumenep. Desa Masalima masuk pada Kecamatan Masalembu, dimana ada 4 Desa di Kecamatan Masalembu yaitu Desa Masalima, Desa Sukajeruk, Desa Karamian, dan Desa Masakambing.

\section{Grafik 4.1 Luas wilayah kecamatan masalembu}

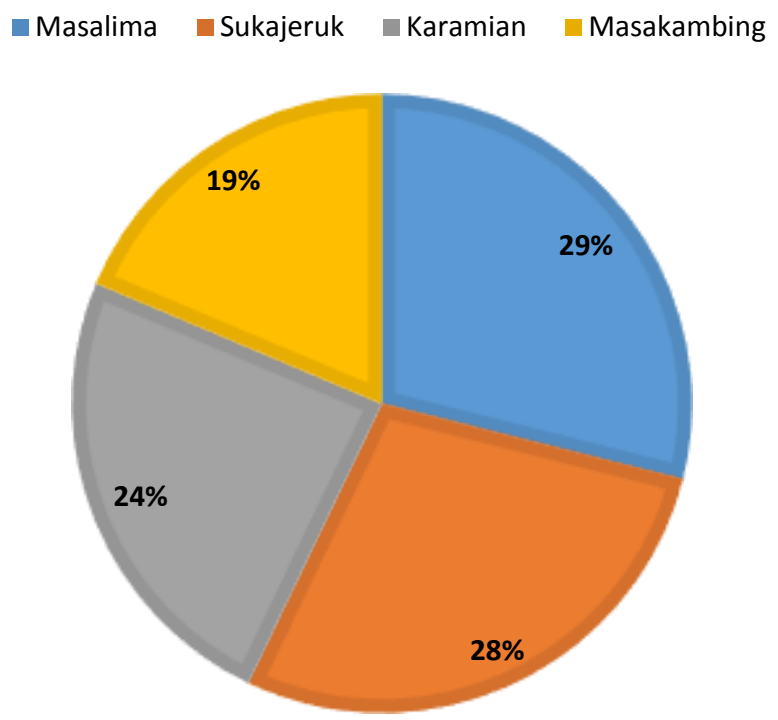

Sumber: Kecamatan Masalembu dalam Angka, Diolah

Grafik di atas menjelaskan bahwa Desa paling luas di Kecamatan Masalembu adalah Desa Masalima dengan luas 12,09 KM persegi atau 29\% 
Jurnal Ekonomi dan Perbankan Syariah

Vol. 6. No.1, April 2018: 107-134, ISSN (cet): 2355-1755 | ISSN (online): 25796437

\section{| 113}

apabila di presentasekan. Dengan luas wilayah yang lebih besar dari pada Desa lain yang ada di Kecamatan Masalembu, Desa Masalima juga Memiliki jumlah penduduk yang lebih banyak dari pada Desa yang lain dengan 9 RW dan 35 RT dengan total penduduknya 10.325 jiwa, terdiri dari 5.130 laki-laki dan 5.195 perempuan. Dari segi agama yang dianut oleh penduduk Desa Masalima Mayoritas Islam dengan jumlah 10.325 jiwa.

\subsubsection{Potensi Desa Masalima}

Desa Masalima dengan luas 12,09 kilometer persegi, berada di jantung Kecamatan Masalembu yang sebagian besar masyarakatnya bekerja di sektor perikanan.

\section{Grafik 4.2 Lapangan Usaha Utama}

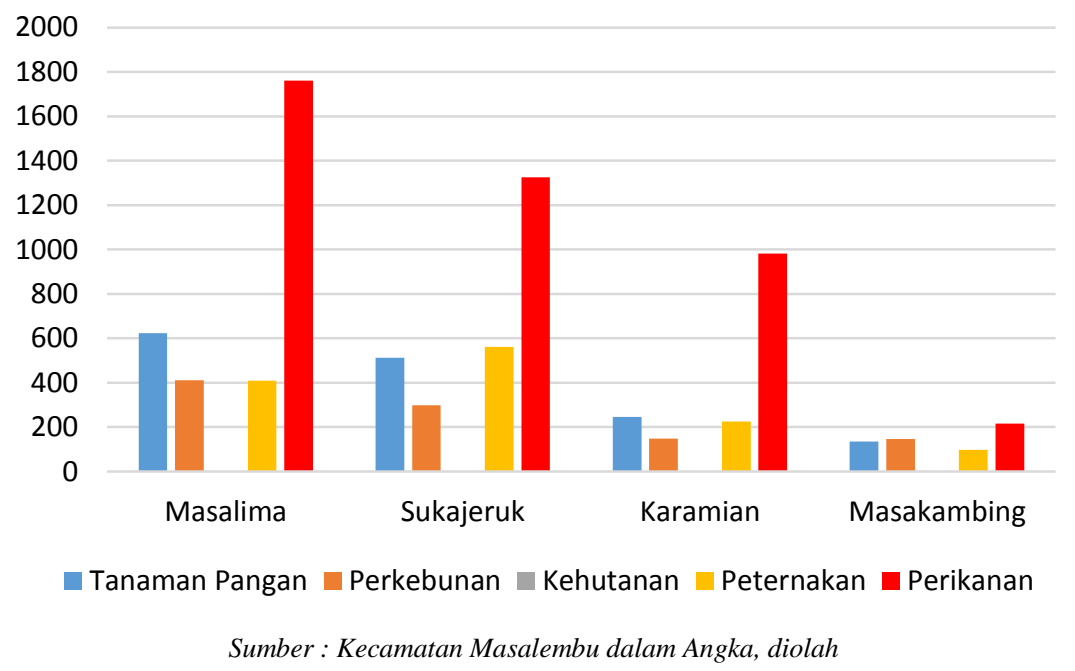

Grafik di atas menunjukkan bahwa banyaknya rumah tangga yang bekerja disektor tanaman pangan di Desa Masalima sebanyak 623 Rumah Tangga, kemudian 512 rumah tangga pada Desa Sukajeruk, 245 rumah tangga pada Desa Karamian, serta ada 135 rumah tangga pada Desa Masakambing. Pada sektor perkebunan, pada Desa Masalima sebanyak 412 rumah tangga, 298 rumah tangga pada Desa Sukajeruk, 149 rumah tangga pada Desa Karamian, serta sebanyak 147 rumah tangga pada Desa Masakambing. Pada sektor kehutanan belum ada rumah tangga yang bergerak di bidang tersebut.

Untuk sektor peternakan, pada Desa Masalima sebanyak 409 rumah tangga, 561 rumah tangga pada Desa Sukajeruk, dan sebanyak 226 rumah tangga pada Desa Karamian, sebanyak 98 rumah tangga pada Desa Masakambing. Sedangkan sektor terbesar dari ke empat desa tersebut adalah 
sektor perikan, dimana pada Desa Masalima sebanyak 1.760 rumah tangga, 1.326 rumah tangga di Desa Sukajeruk, dan sebanyak 982 rumah tangga pada Desa Karamian, serta sebanyak 216 rumah tangga pada Desa Masakambing.

Dari data tersebut menjelaskan bahwa sektor usaha terbesar pada Kecamatan Masalembu adalah sektor perikanan. Dan rumah tangga terbanyak yang bekerja di sektor perikanan adalah di Desa Masalima yaitu sebesar 1.760 rumah tangga.

\section{Grafik 4.3 Perkembangan sektor usaha Perikanan Desa Masalima}

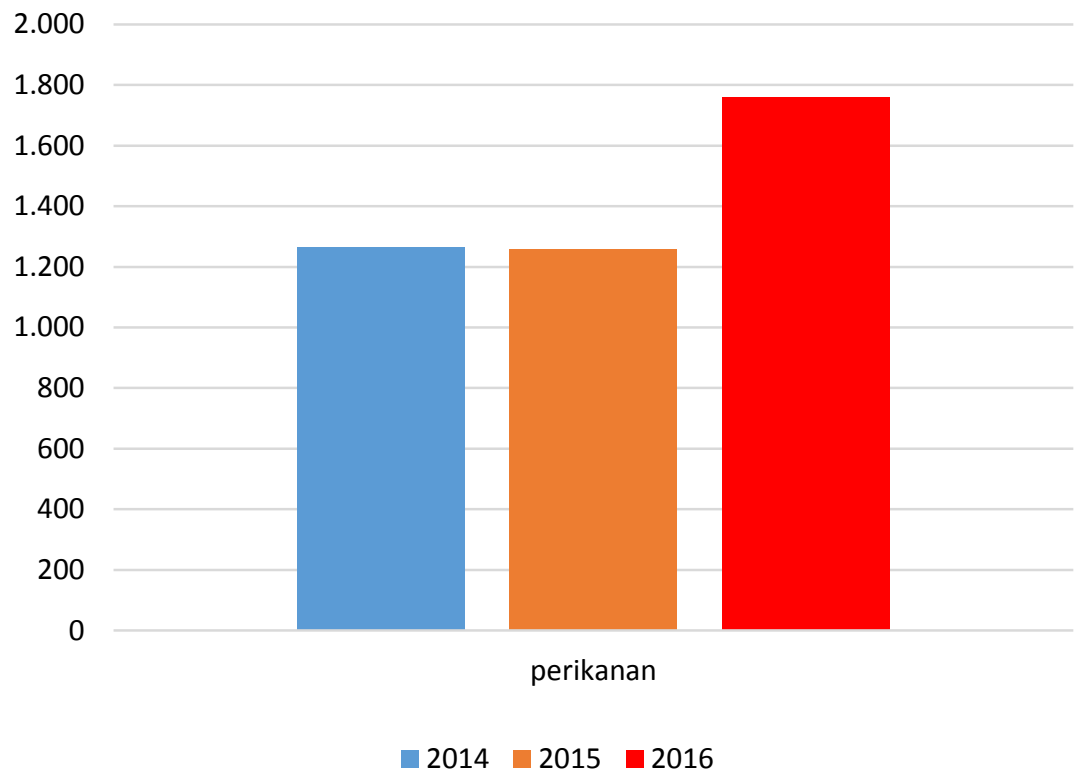

Sumber : Kecamatan Masalembu dalam Angka, diolah

Diagram di atas memperlihatkan bahwa selama tiga tahun berturut-turut jumlah rumah tangga yang bergerak pada sektor perikanan meningkat. Pada tahun 2014 jumlah rumah tangga yang bergerak di sektor perikanan sebanyak 1.265 rumah tangga, sedangkan pada tahun 2015 sebanyak 1.260 rumah tangga, dan pada tahun 2016 sebanyak 1.760 rumah tangga. Tapi dengan meningkatnya rumah tangga yang bergerak di sektor perikanan tidak berdampak signifikan terhadap keadaan perekonomian masyarakat Desa Masalima.

\subsection{ANALISIS SEBELUM DI LAPANGAN}

Analisis ini dilakukan terhadap data hasil studi pendahuluan, atau data sekunder, yang digunakan untuk menentukan fokus penelitian. Adapun beberapa data yang analisis yaitu data yang bersumber dari data sekunder yang berupa data statistik. Seperti pertumbuhan ekonomi, dan mata pencaharian masyarakat Desa Masalima, sehingga nantinya akan dapat ditemukan potensi 
Jurnal Ekonomi dan Perbankan Syariah

Vol. 6. No.1, April 2018: 107-134, ISSN (cet): 2355-1755 | ISSN (online): 25796437

\section{| 115}

desa terbesar yang bisa di kelola oleh BUMDes untuk meningkatkan perekonomian desa tersebut.

\subsubsection{Pertumbuhan Ekonomi}

Pertumbuhan ekonomi merupakan salah satu faktor yang digunakan untuk melihat sejahtera atau tidaknya suatu masyarakat. Untuk Desa Masalima sendiri bisa dilihat pertumbuhan ekonominya dari tahun 2014 sampai tahun 2016 dari grafik berikut :

\section{Grafik 4.3 Perekonomian Desa Masalima}

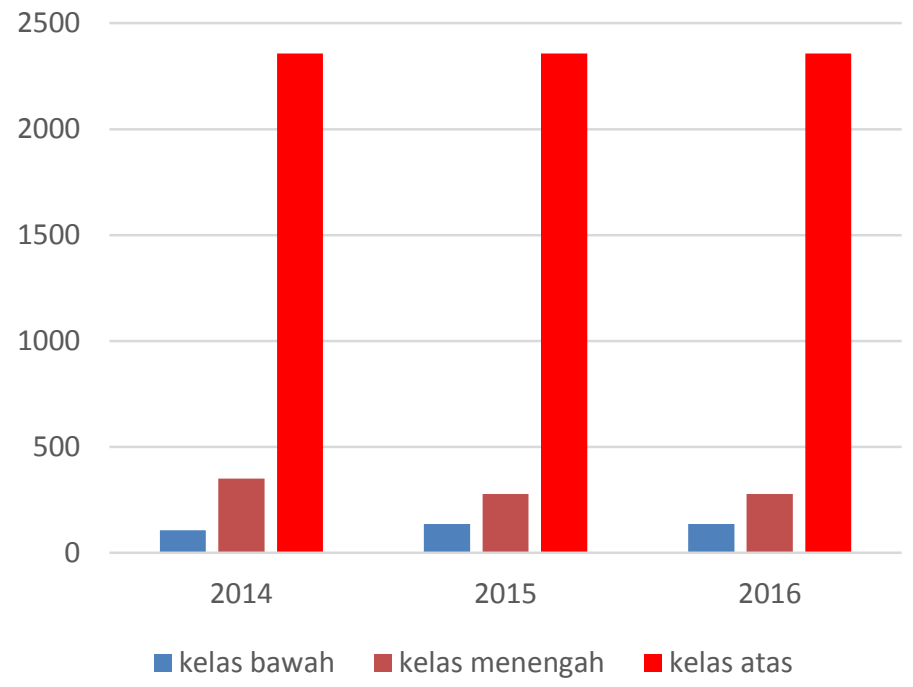

Sumber : kecamatan Masalembu dalam angka, diolah

Dari diagram di atas menjelaskan bahwa, pertumbuhan ekonomi masyarakat Desa Masalima pada tahun 2014 sebanyak 106 keluarga pada kelas bawah, sedangkan sebanyak 350 keluarga pada kelas menengah, dan sebanyak 2.358 keluarga pada kelas atas. Sedangkan pada tahun 2015 sebanyak 136 keluarga pada kelas bawah, kemudian sebanyak 278 keluarga pada kelas menengah, dan sebanyak 2.358 keluarga pada kelas atas. Dan pada tahun 2016 sebanyak 136 keluarga pada kelas bawah, sedangkan sebanyak 278 keluarga pada kelas menengah, dan sebanyak 2.358 keluarga pada kelas atas.

Dari data diatas dapat kita simpulkan bahwa pertumbuhan ekonomi pada kelas atas stabil, dalam artian jumlahnya tetap tidak ada perubahan menurun atau meningkat. Akan tetapi perubahan jumlah dapat dilihat pada kelas menengah dan bawah, hal ini menandakan bahwa perekonomian Masyarakat Desa Masalima memburuk dari tahun 2014 sampai tahun 2016. 
116 | Ryan Marala: Model Pengelolaan Badan Usaha Milik Desa (BUMDes) Dalam Membangun Perekonomian Desa (Studi Kasus Desa Masalima)

\subsubsection{Mata Pencaharian Masyarakat}

\section{Grafik 4.4 Perkembangan sektor usaha Perikanan Desa Masalima}

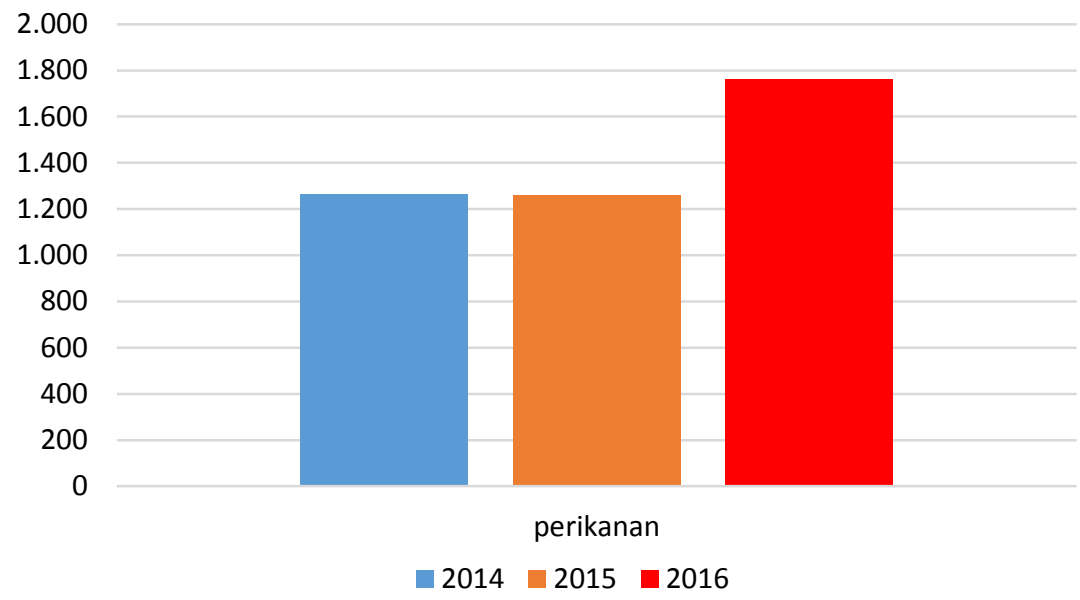

Sumber : Kecamatan Masalembu dalam Angka, diolah

Diagram di atas memperlihatkan bahwa selama tiga tahun berturut-turut jumlah rumah tangga yang bergerak pada sektor perikanan meningkat. Pada tahun 2014 jumlah rumah tangga yang bergerak di sektor perikanan sebanyak 1.265 rumah tangga, sedangkan pada tahun 2015 sebanyak 1.260 rumah tangga, dan pada tahun 2016 sebanyak 1.760 rumah tangga.

Dari diagram tersebut dapat kita simpulkan bahwa dengan meningkatnya rumah tangga yang bergerak di sektor perikanan tidak berdampak signifikan terhadap keadaan perekonomian masyarakat Desa Masalima. Apakah ada faktor lain yang menyebabkan demikian, maka dari itu di adakannya wawancara lapangan terhadap beberapa masyarakat Desa Masalima untuk mengetahui keadaan langsung dari Desa Masalima tersebut.

\subsection{ANALISIS DATA DI LAPANGAN}

Untuk menjawab dari permasalahan data yang ada, maka diadakan analisis data lapangan berupa wawancara dengan beberapa masyarakat Desa masalima. Ternyata ditemukan permasalahan dimana dengan jumlah rumah tangga yang bergerak pada mata pencaharian sektor perikanan meningkat akan tetapi jumlah kelas bawah dan kelas menengah semakin bertambah, disebabkan karena tidak ada pengelolaan kembali hasil tangkapan berupa ikan, sehingga para nelayan tetap mengambil harga murah yang sudah ditetapkan oleh tengkulak ikan. 
Jurnal Ekonomi dan Perbankan Syariah

Vol. 6. No.1, April 2018: 107-134, ISSN (cet): 2355-1755 | ISSN (online): 2579 6437

\section{7}

Ada beberapa sebab mengapa hasil tangkapan tersebut tidak diolah kembali oleh masyarakat nelayan Desa Masalima, diantaranya tidak ada keterampilan atau ide diolah seperti apa dan bagaimana hasil tangkapan tersebut, kemudian pengelolaan tentunya membutuhkan modal besar dan permodalan tersebut menjadi salah satu kendala dalam pengelolaan ikan.

Dari permasalahan tersebut dapat kita simpulkan bahwa harus adanya penyuluhan atau pelatihan terhadap masyarakat Desa Masalima mengenai pengelolaan ikan supaya bisa menghasilkan pendapatan tambahan bagi masyarakat. Bentuk olahan tersebut bisa berupa abon ikan, sarden ikan, kerupuk ikan, dan lain-lain. kemudian untuk permasalahan kedua yaitu permodalan, untuk permodalan sendiri harus ada kerjasama antara pemerintah desa dengan masyarakat desa. Bisa dibentuk Badan Usaha Milik Desa (BUMDes) dimana bisa membuka unit usaha untuk masyarakat nelayan berupa permodalan usaha sehingga hasil tangkapannya bisa di olah kembali.

\subsection{MODEL PENGELOLAAN BADAN USAHA MILIK DESA (BUMDES)}

Pembangunan ekonomi lebih menitik beratkan kepada masyarakat miskin dan masyarakat yang kurang mampu yang mata pencahariannya sebagai petani dan usaha kecil. Maka dari itu pemerintah daerah melalui Badan Usaha Milik Desa (BUMDes) berupaya membantu masyarakat dengan ekonomi menengah kebawah, bukan saja dengan memberikan pinjaman tetapi juga memberikan pendidikan, bimbingan dan konsultasi yang berkaitan dengan usaha dan pekerjaan mereka sehari-hari.

Pada peraturan Menteri Desa no 4 tahun 2015, pendirian Badan Usaha Milik Desa (BUMdes) dimaksudkan sebagai upaya menampung seluruh kegiatan dibidang ekonomi dan atau pelayanan umum yang dikelola oleh Desa dan atau kerja sama antar Desa. Dengan adanya PERMENDES tersebut, membuka harapan baru bagi masyarakat Desa untuk mengembangkan potensi Desa secara optimal. Dengan didukung penuh oleh Pemerintah Desa maka tujuan untuk membentuk Desa mandiri serta memperbaiki perekonomian masyarakat Desa terbuka lebar.

\subsubsection{Pendirian Badan Usaha Milik Desa (BUMDes)}

Pendirian BUMDes yaitu sebagai upaya menampung seluruh kegiatan di bidang ekonomi dan atau pelayanan umum yang dikelola oleh Desa dan atau kerja sama antar Desa (Permendes, 2015). Mengetahui potensi yang ada pada Desa adalah salah satu langkah yang harus diperhatikan sebelum mendirikan Badan Usaha Milik Desa. Khususnya Desa Masalima dengan potensi terbesar adalah hasil lautnya, maka badan usaha yang didirikan nantinya harus mendukung potensi tersebut sehingga bisa dikelola dengan baik dan menghasilkan pendapatan yang optimal bagi masyarakat Desa Masalima.

Pengelolaan tersebut bisa dilakukan dengan adanya sinergi antara Pemerintah dan Masyarakat Desa. Sinergi tersebut bisa menggunakan model 
Co-Management, dimana adanya pembagian tugas antara Pemerintah dan Masyarakat untuk mencapai tujuan bersama.

Untuk pengelolaan hasil laut pada Desa Masalima sendiri, bisa diolah kembali hasil lautnya berupa abon ikan, sarden ikan, kerupuk ikan, dan lainlain. dengan diolah ulang dengan menghasilkan produk dan tidak dijual secara langsung pada tengkulak dimana harga penjualannya sering murah sehingga pengahasilan masyarakat nelayan tidak optimal. Dengan pengelolaan ulang tersebut, dapat menghasilkan pendapatan diatas rata-rata, dan tidak bergantung lagi dengan musim ikan. Sehingga pada saat tidak musim melaut, masyarakat nelayan masih bisa menghasilkan pendapatan tidak harus meninggalkan Desa dan keluar dari Desa untuk mencari pekerjaan lain.

Itulah potensi utama Desa Masalima yang harus dikembangkan dan dioptimalkan. Dengan berdirinya badan usaha milik Desa nantinya, bisa menjadikan hasil pengelolaan hasil laut tersebut sebagai produk utama dari BUMDes tersebut untuk mengoptimalkan pendapatan Desa dan mensejahterakan Masyarakat Desa.

\subsubsection{Modal Badan Usaha Milik Desa (BUMDes)}

Berdasarkan PERMENDES no 4 tahun 2015 pasal 17 menyatakan bahwa, modal awal Badan Usaha Milik Desa (BUMDes) bersumber dari APB Desa. Modal BUMDes terdiri atas Penyertaan modal Desa dan Penyertaan modal masyarkat Desa. Yang dimaksud dengan penyertaan modal Desa adalah hibah dari pihak swasta, bantuan Pemerintah, Kerjasama usaha dari pihak Swasta, dan aset Desa yang diserahkan kepada APB Desa sesuai dengan ketentuan peraturan perundang-undangan tentang Aset Desa Pengelolaan Badan Usaha Milik Desa (BUMDes).

Dimana telah di cantumkan dalam PERMENDES no 4 tahun 2015 pasal 9 bahwa pengelolaan BUMDes terpisah dari organisasi Pemerintahan Desa. Jadi kepengurusan Badan Usaha Milik Desa (BUMDes) harus terpisah dari kepengurusan Pemerintahan Desa yang ada. Dan dijelaskan kembali pada PERMENDES no 4 tahun 2015 pasal 16 tentang susunan kepengurusan BUMDes dipilih oleh masyarakat melalui Musyawarah Desa sesuai dengan ketentuan dalam Peraturan Menteri tentang Pedoman Tata Tertib dan Mekanisme Pengambilan Keputusan Musyawarah Desa.

Susunan kepengurusan organisasi pengelola Badan Usaha Milik Desa (BUMDes) terdiri dari :

a. Penasihat.

b. Pelaksana Operasional.

c. Pengawas.

Adapun Penasihat mempunyai kewajiban memberikan nasihat kepada pelaksana operasional dalam melaksanakan pengelolaan BUMDes, kemudian memberikan saran dan pendapat mengenai masalah yang dianggap penting bagi pengelolaan BUMDes, serta mengendalikan pelaksanaan kegiatan pengelolaan BUMDes.

Selain itu, Penasihat juga mempunyai wewenang terhadap pengelolaan Badan Usaha Milik Desa (BUMDes), antara lain meminta penjelasan dari 
Jurnal Ekonomi dan Perbankan Syariah

Vol. 6. No.1, April 2018: 107-134, ISSN (cet): 2355-1755 | ISSN (online): 25796437

\section{9}

pelaksana operasional mengenai persoalan yang menyangkut pengelolaan usaha Desa serta melindungi usaha Desa terhadap hal-hal yang dapat menurunkan kinerja Badan Usaha Milik Desa (BUMDes).

Dengan adanya penasihat maka operasional dalam pengelolaan BUMDes akan berjalan sesuai dengan ketentuan yang ada. Oleh karena itu penasihat disini harus selalu mengontrol dan mendampingi pengurus operasional.

Kemudian untuk operasional Badan Usaha Milik Desa (BUMDes) mempunyai tugas dan mengelola BUMDes sesuai dengan Anggaran Dasar dan Anggaran Rumah Tangga. Operasional disini mempunyai kewajiban untuk melaksanakan dan mengembangkan BUMDes agar menjadi lembaga yang melayani kebutuhan ekonomi dan atau pelayanan umum masyarakat Desa kemudian menggali dan memanfaatkan potensi usaha ekonomi Desa untuk meningkatkan pendapatan asli Desa, serta melakukan kerjasama dengan lembaga-lembaga perekonomian desa lainnya.

Operasional Badan Usaha Milik Desa (BUMDes) juga memiliki wewenang membuat laporan keuangan seluruh unit-unit usaha BUMDes setiap bulan kemudian membuat laporan perkembangan kegiatan unit-unit usaha BUMDes setiap bulan, serta memberikan laporan perkembangan unit-unit usaha BUMDes kepada masyarakat Desa melalui musyawarah desa sekurangkurangnya dua kali dalam satu tahun.

Bagian operasional harus mempunyai strategi yang matang dan analisis yang tajam dalam melaksanakan tugasnya karena berdampak langsung dengan keberadaan dan keberlangsungan BUMDes kedepannya. Harus tahu betul apa yang menjadi potensi utama dari Desa sehingga bisa dioptimalkan sehingga menghasilkan profit dan omset yang maksimal, sehingga bisa menciptakan Badan Usaha Milik Desa yang mandiri. Karena akan berdampak besar juga terhadap Desa, apabila Badan Usaha Milik Desa berjalan dengan baik maka kedepannya akan terwujud Desa yang Mandiri.

Satu bagian penting juga untuk keberlangsungan Badan Usaha Milik Desa (BUMDes), yaitu pengawas. Dengan adanya pengawas maka aspirasi dari masyarakat akan tersampaikan karena tugas dari pengawas disini adalah mewakili kepentingan Masyarakat.

Pengawas juga mempunyai kewajiban menyelenggarakan rapat umum untuk membahas kinerja BUMDes sekurang-kurangnya satu tahun sekali. Kemudian pengawas juga mempunyai wewenang menyelenggarakan rapat umum pengawas untuk pemilihan dan pengangkatan pengurus kemudian menetapkan kebijakan pengembangan kegiatan usaha dari BUMDes, serta melaksanakan pemantauan dn evaluasi terhadap kinerja pelaksana operasional.

Adapun susunan kepengurusan Pengawas Menurut PERMENDES no 4 tahun 2015 pasal 15 yaitu :

a. Ketua.

b. Wakil Ketua merangkap anggota.

c. Sekretaris merangkap anggota. 
d. Anggota.

Kemudian syarat untuk menjadi pelaksana opersional meliputi :

a. Masyarakat Desa yang mempunyai jiwa Wirausaha.

b. Berdomisili dan menetap di Desa sekurang-kurangnya 2 (dua) tahun.

c. Berkepribadian baik, jujur, adil, cakap, dan perhatian terhadap usaha ekonomi Desa.

d. Pendidikan minimal setingkat SMU/Madrasah Aliyah/SMK atau sederajat.

Pembentukan dan pengelolaan Badan Usaha Milik Desa di Desa Masalima harus sesuai dengan dasar hukum yang ada yaitu PERMENDES no 4 tahun 2015 tentang Pendirian, Pengurusan dan Pengelolaan, dan Pembubaran Badan Usaha Milik Desa,sehingga anggaran dasar dan anggaran rumah tangga yang dibuat nantinya juga sesuai dengan peraturan yang berlaku. Selanjutnya struktur organisasi disesuaikan dengan kebutuhan.

\subsubsection{Struktur Organisasi BUMDes}

BUMDes merupakan sebuah organisasi, maka diperlukan adanya struktur organisasi yang menggambarkan bidang pekerjaan apa saja yang harus tercakup di dalam organisasi tersebut. Bentuk hubungan kerja (instruksi, konsultatif, dan pertanggunganjawab) antar personil atau pengelola BUMDes (Nasional, Ekonomi, \& Brawijaya, 2007). Dalam pendirian BUMDes, harus ada struktur untuk pengorganisasian dan pengawasan dalam pelaksanaan kinerja BUMDes nanti kedepannya. Struktur BUMDes sendiri sudah diatur dalam PERMENDES no 4 tahun 2015, beserta jobdesk-nya juga sudah diatur dengan jelas. Akan tetapi, penggunaan suatu Devisi dalam struktur BUMDes diserahkan kembali pada Desa sesuai dengan kebutuhan.

Dengan potensi Desa yang ada pada Desa Masalima, maka berfokus pada pengelolaan dan pengoptimalan hasil laut. Oleh karena itu struktur yang dibuat dalam pelaksanaan BUMDes nantinya harus mendukung untuk kebutuhan pengoptimalan baik sumberdaya manusia maupun sumberdaya alam dan potensi yang ada.

\subsubsection{Menyusun Rencana usaha}

Penyusunan rencana usaha penting untuk dibuat dalam periode 1 sampai dengan 3 tahun. Sehingga para pengelola BUMDes memiliki pedoman yang jelas apa yang harus dikerjakan dan dihasilkan dalam upaya mencapai tujuan yang ditetapkan dan kinerjanya menjadi terukur. Penyusunan rencana usaha dibuat bersama dengan Dewan Komisaris BUMDes (Nasional et al., 2007). Dengan adanya rencana usaha pada Badan Usaha Milik desa (BUMDes), maka kinerja dari struktur yang ada akan semakin jelas. Kemudian harus menentukan dan bisa membentuk suatu unit usaha seperti simpan pinjam, pasar desa, pertanian, obyek wisata desa, peternakan, kerajinan rakyat, sumber air, agroindustri, dan lain-lain.

Mengoptimalkan adanya Badan Usaha Milik Desa (BUMDes) dengan adanya unit-unit usaha yang dikelola oleh BUMDes sendiri, maka akan membentuk suatu siklus perekonomian desa yang stabil. Dengan adanya unit 
Jurnal Ekonomi dan Perbankan Syariah

Vol. 6. No.1, April 2018: 107-134, ISSN (cet): 2355-1755 | ISSN (online): 2579 6437

\section{| 121}

usaha seperti simpan pinjam, maka akan ada pembiayaan permodalan usaha untuk masyarakat desa dan bisa meningkatkan omset bumdes tersebut.

Dengan adanya sistem simpan pinjam pada BUMDes, maka masalah permodalan untuk memulai usaha bukan suatu masalah lagi bagi masyarakat desa. Untuk mengelola hasil laut pada masyarakat nelayan Desa Masalima tentunya semakin mudah karena adanya sistem simpan pinjam. maka hasil laut tersebut bisa dikelola kembali bisa diolah kembali berupa abon ikan, kerupuk ikan, sambal ikan, kerupuk amplang, dan lain sebagainya yang berasal dari bahan ikan. Dengan adanya produk tersebut maka pendapatan masyarakat desa akan meningkat dan akan berdampak juga terhadap BUMDes Desa Masalima nantinya.

\subsubsection{Merintis Unit Usaha Baru di BUMDes}

BUMDes dapat berfungsi mewadahi berbagai usaha yang dikembangkan di pedesaan. Oleh karena itu, di dalam BUMDes dapat terdiri dari beberapa unit usaha berbeda-beda (Nasional et al., 2007). Unit usaha yang berada di dalam BUMDes secara umum dapat dibedakan menjadi dua yaitu :

1. Unit Jasa Keuangan, misalnya menjalankan usaha simpan pinjam.

2. Unit usaha sektor rill/ekonomi, misalnya menjalankan usaha pertokoan atau waserda, foto copy, sablon, home, industri, pengelolaan taman wisata desa, peternakan, perikanan, pertanian, dan lain-lain.

Untuk merintis unit usaha baru pada Badan Usaha Milik Desa (BUMDes), ada beberapa langkah yang harus di perhatikan yaitu :

1. Menentukan siapa konsumen sasarannya (target pasar)

2. Melakukan identifikasi kebutuhan, keinginan dan daya belinya

3. Melayani salah satu kebutuhan dan keinginannya yang bersifat jangka panjang dan menguntungkan.

4. Mendirikan unit usaha untuk memenuhi kebutuhan pasar tersebut, misalnya:

a) Bila kebutuhan utama konsumen sasaran adalah sarana transportasi, maka dibuka unit usaha jasa transportasi.

b) Bila kebutuhan utama konsumen sasaran adalah kebutuhan seharihari, maka dirikan unit waserda atau minimarket.

c) Bila kebutuhan utama konsumen sasaran adalah bahan baku untuk memproduksi tahu/tempe, maka dibuka unit usaha yang melayani kebutuhan kedelai dengan kualitas sebagaimana yang diinginkan.

5. Usaha promosi produk, baik melalui media online ataupun offline. Tujuan dari promosi adalah menginformasikan kepada konsumen sasaran berkenaan dengan penyediaan barang atau jasa yang masyarakat butuhkan dan inginkan.

6. Perlu dibuat perhitungan yang seksama menyangkut tingkat pengembalian modal usaha yang digunakan. Sehingga pengelolaan dan Dewan Komisaris dapat mengetahui pada tahun keberapa usahanya mulai berbuah atau menghasilkan keuntungan dan modalnya sudah kembali. 
7. Pelayanan yang baik, bersahabat dan ramah harus dijadikan sebagai landasan dalam menjalin kerjasama dengan para konsumen.

8. Selalu melakukan inovasi produk untuk meningkatkan daya saing dengan produk yang ada di pasar.

Dengan memperhatikan beberapa hal tersebut, maka unit usaha pada bumdes akan berjalan dengan baik kedepannya. Untuk produk-produk olahan dari hasil laut seperti abon ikan, krupuk ikan, kerupuk amplang dan lain-lain, dapat dijual atau dipasarkan baik di pasar dalam desa ataupun pasar diluar desa.

Ada beberapa BUMDes yang sudah berdiri di Indonesia dan mendapat penghargaan dari pemerintah dikarenakan prestasi yang dicapai BUMDes tersebut, diantaranya Desa Amin Jaya, Kecamatan Pangkalan Banteng, Kabupaten Kotawaringin Barat, Kalimantan Tengah, ini. Berkat BUMDesa bernama Karya Jaya Abadi, ekonomi warga desa menjadi jauh lebih baik dan tak perlu tertindas di bawah tengkulak kelapa sawit. Berdiri Maret 2014, BUMDesa Karya Jaya Abadi memposisikan diri sebagai pembeli sawit dari warga secara langsung. Baru setelah itu sawit-sawit itu dijual ke pabrik-pabrik yang ada di sekitar daerah ini. Hasilnya, desa yang sebagian besar warganya hidup dari kelapa sawit ini menjadi lebih sejahtera karena tidak lagi dilindas tengkulak sawit yang selama ini merajalela.

Langkah berani dan inovatif inilah yang membuat BUMDesa Karya jaya Abadi menyabet gelar Pemenang Nasional BUMDesa Kreatif seIndonesia 2016 dalam gelar pemilihan BUMDesa terbaik se-Indonesia oleh Kementerian Desa dan Pembangunan Daerah Tertinggal dan Transmigrasi, baru-baru ini.

Berbeda lagi dengan BUMDesa Tamangalle Bisa lahir, warga Desa Tamangalle, Kecamatan Balanipa, Polewali Mandar, Sulawesi Barat, kini bisa bernafas lega. Sarung tenun sutra buatan mereka laris manis tanjung kimpul. Inilah yang membuat Tamangalle Bisa menjadi salahsatu BUMDesa Terbaik Kategori BUMDesa Rintisan Handy Caft dan Kerajinan Desain.

Sarung Sutra buatan Tamangalle bukan tenun biasa. Dari desa saja sarung ini sudah dibandrol Rp 200 - 400 ribu selembar. Di bawah pengelolaan BUMDesa kini 25 orang penenun membuat sarung khas desa mereka setiap hari, pada masa awal BUMDesa berdiri hanya ada 15 orang saja. Penanganan hasil tenun warga oleh BUMDesa awalnya bermodal Rp. 50 juta dari dana desa dan kini terus mengembang. Untuk melebarkan pemasaran, BUMDesa memanfaatkan pameran produk dan jaringan media sosial. Kemampuan membaca potensi desa berupa kerajinan tenun membuat desa ini terpilih menjadi BUMDesa Terbaik oleh Kementerian, Pembangunan Daerah Tertinggal dan Transmigrasi, baru-baru ini untuk Kategori Kategori Rintisan Handycraft - Kerajinan Disain BUMDes.

Dari beberapa contoh BUMDes tersebut, dapat dikatakan bahwa dengan adanya BUMDes bisa merubah perekonomian masyarakat desa dengan mengoptimalkan potensi desa yang ada, dengan kerjasama antara pemerintah desa dengan masyarakat. 
Jurnal Ekonomi dan Perbankan Syariah

Vol. 6. No.1, April 2018: 107-134, ISSN (cet): 2355-1755 | ISSN (online): 2579-

6437

\section{3}

\subsubsection{Permodalan Usaha Masyarakat Melalui BUMDes}

Mengoptimalkan hasil laut dan potensi desa tentunya membutuhkan modal yang lumayan besar. Dengan pendapatan penduduk Desa Masalima yang dibawah rata-rata, maka membutuhkan modal tambahan. Dengan demikian, unit usaha yang ada pada BUMDes seperti unit usaha simpan pinjam akan sangat membantu dalam proses permodalan hingga penjualan produk olahan hasil laut yang dikelola oleh masyarakat desa. Dengan adanya permodalan usaha melalui BUMDes untuk masyarakat, maka akan meringankan beban masyarakat dalam masalah permodalan usaha mereka. Tapi harus ada ketentuan khusus yang harus diperhatikan saat memberikan permodalan untuk masyarakat seperti akad yang digunakan nantinya seperti apa, kemudian kalau ada sistem bagi hasil berapa persen bagian buat BUMDes dan berapa persen untuk masyarakat.

Terkait akad yang akan digunakan yaitu bisa jadi ada dua pilihan, yaitu mudharabah dan musyarakah. Dimana menggunakan akad mudharabah apabila permodalan sepenuhnya dari BUMDes dan masyarakat hanya mengelola usahanya kemudian ada bagi hasil dari pendapatan penjualan olahan hasil laut nantinya. Kemudian menggunakan akad musyarakah apabila masyarakat mempunyai modal akan tetapi belum mencukupi untuk membuka usaha sehingga mengajukan permodalan kepada BUMDes, sehingga samasama memberikan modal dan nantinya ada sistem bagi hasil sesuai besar keuntungan.

Akan tetapi, apapun akad yang akan digunakan nantinya, harus ada bimbingan dan pengawasan dari BUMDes terhadap usaha yang dijalankan oleh masyarakat tersebut, untuk meminimalisir kerugian sehingga bisa memperoleh pendapatan yang optimal. Mungkin saat ini banyak masyarakat diluar sana yang menggunakan sistem bunga dalam permodalan, akan tetapi sistem bunga tersebut sebenarnya memberatkan masyarakat. Keuntungan yang didapat dari usaha terkadang lebih kecil dari pada bunga yang harus dibayarkan kepada pemberi modal. Maka dari itu, sistem bagi hasil lah yang paling tepat digunakan untuk permodalan di BUMDes. Selain sitem dan keuntungan jelas, sistem bagi hasil juga bisa menjadi suatu kelebihan dari BUMDes tersebut yaitu memudahkan masyarakat bukan memberatkan masyarakat.

\section{KESIMPULAN}

Penelitian ini dimaksudkan untuk mengkaji pendirian dan pengelolaan Badan Usaha Milik Desa (BUMDes). Berdasarkan uraian hasil analisis pada bab sebelumnya, maka ditarik kesimpulan bahwa dengan keadaan ekonomi masyarakat Desa Masalima saat ini, dimana mayoritas penduduknya adalah nelayan yang hanya bergantung hidup dari hasil lautnya saja. Sedangkan penangkapan ikan di Desa Masalima hanya musiman, sehingga apabila musim melaut berakhir maka masyarakat Desa Masalima hanya ada dua pilihan yaitu menggunakan tabungannya untuk bertahan hidup selama tidak musim melaut atau pergi ke kota-kota besar untuk mencari pekerjaan lain. dengan kondisi 
seperti itu menandakan bahwa perekonomian Desa Masalima masih belum stabil, maka dengan adanya Badan Usaha Milik Desa (BUMDes) yang di kelola sendiri oleh pemerinah Desa dan juga oleh masyarakat, maka akan ada upaya untuk mengoptimalkan potensi desa yang ada utamanya hasil laut pada Desa Masalima.

Peran BUMDes sendiri sangat dibutuhkan oleh masyarakat, utamanya dalam hal pemberian modal usaha bagi masyarakat Desa Masalima. Dengan adanya layanan pemberian modal usaha maka akan ada sistem bagi hasil yang akan meningkatkan pendapatan, baik pendapatan bagi BUMDes sendiri ataupun pendapatan bagi masyarakat. Dengan terjalin sistem seperti demikian, maka kesejahteraan masyarakat Desa Masalima akan membaik dikarenakan ada lembaga

\section{DAFTAR PUSTAKA}

Algumeri, M. (2013). Analisis Faktor Penyebab Kredit Macet Pada Bumdes Mitra Bersama Desa Bengkolan Salak.

Andi Siti Sri Hutami. (2017). Analisis Pengelolaan Alokasi Dana Desa (Add) Di Desa Abbatireng Kecamatan Gilireng, Kabupaten Wajo.

J.R. Raco. (2010). Metode Penelitian Kualitatif Jenis, Karakteristik dan keunggulannya.

Hayyuna, R., Pratiwi, R. N., Mindarti, L. I., Publik, J. A., Administrasi, F. I., \& Brawijaya, U. (2005). Dalam Rangka Meningkatkan Pendapatan Desa ( Studi Pada BUMDES Di Desa Sekapuk , Kecamatan Ujungpangkah , Kabupaten Gresik ), 2(72), 1-5.

Indriastuti, B. (2009). Kajian Tentang Pengelolaan Usaha Pada Industri Kecil Konveksi Di Desa Tempursari Kecamatan Ngawen Kabupaten Klaten.

Nasional, D. P., Ekonomi, F., \& Brawijaya, U. (2007). Buku Panduan Pendirian dan Pengelolaan Badan Usaha Milik Desa (BUMDes).

Permendes. (2015). Peraturan Menteri Desa, Pembangunan Daerah Tertinggal, Dan Transmigrasi Republik Indonesia, 1-11.

Pirdaus. (2014). Intern Pemberian Kredit Pada Badan Usaha Milik Desa ( Bumdes ) Bina Usaha Desa Kepenuhan Barat.

Sugiyono. (2017). Metode Penelitian Kuantitatif, Kualitatif, Dan R\&D.

Indah Susilowati, M.Sc., P. . (2012). Menuju Pengelolaan Sumberdaya Perikanan Berkelanjutan Yang Berbasis Pada Ekosistem : Studi Empiris Di Karimunjawa, Jawa Tengah, (November).

Purnamasari, N. (2014). Badan Usaha Milik Desa (Dalam Alur Regulasi) Menghidupkan Desa.

Ramadana, C. B., \& Ribawanto, H. (2010). Keberadaan Badan Usaha Milik Desa (Bumdes) Sebagai Penguatan Ekonomi Desa (Studi di Desa Landungsari, Kecamatan Dau, Kabupaten Malang), 1(6), 1068-1076.

Ridlwan, Z. (2014). Urgensi badan usaha milik desa (bumdes) dalam pembangun perekonomian desa. Fiat Justisia Jurnal Ilmu Hukum, 8, 424-440. 
Jurnal Ekonomi dan Perbankan Syariah

Vol. 6. No.1, April 2018: 107-134, ISSN (cet): 2355-1755 | ISSN (online): 25796437

| 125

Sulastri, N. (2016). Efektivitas Pengelolaan Alokasi Dana Desa (Add) Dalam Meningkatkan Pembangunan Fisik Desa Lakapodo Kecamatan Watopute Kabupaten Muna.

Wijanarko, B. (2006). Program Pascasarjana Di Pantai Utara Kota Surabaya Dengan Pendekatan Co-Management. 